\title{
PARTISIPASI MASYARAKAT DALAM PEMBANGUNAN HUTAN RAKYAT DI KABUPATEN KUBU RAYA KALIMANTAN BARAT
}

\section{COMMUNITY PARTICIPATION IN 'HUTAN RAKYAT’ DEVELOPMENT IN KUBU RAYA DISTRICT, WEST KALIMANTAN}

\author{
Widiya Octa Selfiany ${ }^{1)}$, Sigit Normagiat ${ }^{{ }^{*}}$, \\ ${ }^{1}$ Program Studi Kehutanan, Fakultas Pertanian, Universitas Kapuas Sintang \\ 2Program Studi Agroteknologi, Universitas Nahdlatul Ulama Kalimantan Barat \\ *e-mail: sigitnormagiat@unukalbar.ac.id
}

\begin{abstract}
The government of Kubu Raya District has created a Forest and Land Rehabilitation program by assisting in the development of 'Hutan Rakyat' (HR) on community-owned land. This program aims to enable the recipient community to maintain and even increase the presence of HR in their area. but the success of the program needs to be reviewed from the level of community participation. This study aims to measure the level of community participation in HR management in two sample villages in Kubu Raya District. Using descriptive and inferential methods to analyze the influence of internal and external factors on the level of community participation in HR management. The internal factors consist of age, sex, education, income, and length of stay did not have a significant influence on community participation in HR management programs. based on the analysis of community participation using the Arnstein criteria, the scores of both Kubu Padi and Bintang Mas Villages were at level 4 (four) or level of consultation. This means that the community participates based on directions from the relevant institutions, especially when planting in the field. Ideas and inputs from the community are only heard but not necessarily realized in the planning and evaluation stages. The existence of external factors in the form of counselling and market opportunities are considered the potential in encouraging community initiatives to participate in HR development programs.
\end{abstract}

Keywords: hutan rakyat, Kubu Raya District, community, participation

\begin{abstract}
ABSTRAK
Pemerintah Kabupaten Kubu Raya telah membuat program Rehabilitasi Hutan dan Lahan dengan memberikan bantuan bagi pembangunan Hutan Rakyat (HR) di lahan milik masyarakat. Program ini bertujuan agar masyarakat penerima dapat mempertahankan bahkan lebih meningkatkan keberadaan HR di wilayahnya. Namun, keberhasilan program tersebut perlu ditinjau dari tingkat partipasi masyarakat. Penelitian ini bertujuan untuk mengukur tingkat partisipasi masyarakat dalam pengelolaan HR di desa Kubu Padi dan Bintang Mas. Penelitian menggunakan metode deskriptif dan inferensial untuk menganalisis pengaruh faktor internal dan eksternal terhadap tingkat partisipasi masyarakat dalam pengelolaan HR. Hasilnya faktor internal yang terdiri perbedaan umur, jenis kelamin, pendidikan, penghasilan, dan lama tinggal tidak memberikan pengaruh nyata dalam partisipasi masyarakat untuk mengikuti program pengelolaan HR. Berdasarkan analisis partisipasi masyarakat menggunkan kriteria Arnstein diperoleh skor kedua desa berada pada tingkat 4 (empat) atau pada tingkat konsultasi. Ini berarti masyarakat berpartisipasi berdasarkan arahan dari instansi terkait, terutama di saat penanaman di lapangan. Ide-ide serta masukan dari masyarakat hanya didengar, tetapi belum tentu diwujudkan dalam tahapan perencanaan maupun evaluasi. Adanya faktor eksternal berupa penyuluhan dan peluang pasar dinilai berpotensi dalam mendorong inisiatif masayarakat untuk berpartisipasi dalam program pengembangan HR.
\end{abstract}

Kata kunci: hutan rakyat, Kabupaten Kubu Raya, masyarakat, partisipasi 


\section{PENDAHULUAN}

\begin{abstract}
Pemerintah Kabupaten Kubu Raya membuat suatu program Rehabilitasi Hutan dan Lahan dari Dana Alokasi Khusus (DAK) Bidang Kehutanan dan Dana Bagi Hasil (DBH) SDA Kehutanan. Program tersebut terealisasi pada tahun 2010 dalam bentuk pembangunan hutan rakyat (HR). Pemerintah Kubu Raya memberikan bantuan berupa pemberian bibit tanaman, sarana dan prasarana kegiatan, serta upah kerja kepada masyarakat yang bersedia mengusahakan HR di lahan yang berstatus hak milik. Melalui program ini diharapkan membuat masyarakat tetap mempertahankan tutupan hutan di wilayah desa serta hasilnya dapat memperbaiki perekonomian keluarga.
\end{abstract}

Pengembangan HR perlu dianalisis dengan tujuan meningkatkan pengelolaan hutan untuk mengatasi lahan kritis yang berada pada lahan milik masyarakat di sekitar hutan. Masyarakat harus dipacu semangatnya untuk membangun HR agar lahan-lahan milik mereka dapat memberikan hasil bagi peningkatan sumber ekonomi mereka. Partisipasi masyarakat dalam pembangunan HR ini dapat dilakukan dalam dua cara yaitu, berpartisipasi secara langsung dan tidak langsung. Partisipasi masyarakat juga dapat dilakukan dalam berbagai tahapan kegiatan, mulai dari tahapan perencanaan, tahap pelaksanaan hingga tahap pengawasan. Dengan adanya keterlibatan masyarakat dalam pengelolaan hutan, maka diharapkan kelestarian fungsi ekologis dan fungsi ekonomis dari HR dapat berdampak secara langsung kepada masyarakat sekitar hutan. Selain itu, dengan meningkatnya kesadaran masyarakat di sekitar hutan dalam menjaga dan mengelola kelestarian hutan maka akan mengurangi laju deforestasi dan degradasi lahan.

Hasil penelitian sebelumnya yang dilaksanakan oleh Suryaningsih (2012) menginformasikan tentang Hutan Rakyat Desa Karangrejo, Kecamatan Loana, Kabupaten Purworejo dan menunjukkan bahwa masyarakat Desa Karangrejo mendukung dan berperan dalam upaya pelestarian hutan rakyat. Hal ini dikarenakan keberadaan HR yang disadari sangat penting bagi kehidupan mereka. Upaya penanaman dan pemeliharaan tanaman terus mereka lakukan agar HR tetap terjaga dan berfungsi optimal. Selanjutnya, Waluyo, dkk. (2010) dalam penelitiannya menyampaikan bahwa pengembangan HR di Sumatera Selatan menujukkan hasil yang berbeda. Diketahui bahwa masyarakat setempat kurang berperan dalam program HR dengan lokasi kerawanan bencana. Hal tersebut ditunjukkan dengan belum adanya tindakan masyarakat untuk menanam tanaman kehutanan di lahan yang dimiliki. Responden di kedua desa hanya sebatas mempunyai keinginan untuk menanam tanaman kehutanan, tetapi belum melakukannya. Adiwinata dan Yuliana (2012) dalam penelitian Program Pengelolaan Hutan Bersama Masyarakat (PHBM) Perhutani juga melaporkan bahwa partisipasi petani masih sangat rendah. Rendahnya partisipasi petani dalam program ini karena tingkat pendidikan petani yang rendah, umur petani yang lebih dari 50 tahun, tingkat pendapatan petani yang rendah, serta lahan garapan yang sempit. Kemudian, penelitian tentang Motivasi dan Partisipasi Petani dalam Pengelolaan Hutan Kemiri di Kabupaten Maros, Provinsi Sulawesi Selatan yang dilakukan Suprayitno, dkk. (2012) menunjukkan bahwa tingkat partisipasi petani sekitar hutan dalam pengelolaan hutan kemiri tergolong rendah, terbatas pada dua

13 | Jurnal Borneo Akcaya 
tahapan partisipasi yaitu, partisipasi dalam melaksanakan kegiatan pengelolaan hutan kemiri dan partisipasi dalam menikmati atau memanfaatkan hasil hutan, dimana kedua tahapan partisipasi tersebut cenderung rendah. Partisipasi petani sekitar hutan kemiri masih bersifat parsial.

Berdasarkan penelitian-penelitian yang telah dilakukan, belum ada penelitian tentang partisipasi masyarakat pengelola HR di Kalimantan Barat, khususnya di Kabupaten Kubu Raya. Berkenaan dengan hal tersebut maka perlu dilakukan suatu penelitian tentang partisipasi masyarakat dalam pembangunan HR di Kabupaten Kubu Raya. Adapun tujuan dari penelitian ini adalah untuk membahas tentang karakteristik masyarakat, karakteristik $\mathrm{HR}$, tingkat partisipasi masyarakat, dan faktor yang mempengaruhinya. Hasil penelitian diharapkan dapat memberikan gambaran tentang dinamika pembangunan $\mathrm{HR}$ di Kabupaten Kubu Raya dan dapat menjadi acuan dalam hal pembangunan HR di masa datang.

\section{METODE}

Penelitian ini dilaksanakan di Kabupaten Kubu Raya dengan lokus penelitian di Desa Kubu Padi, Kecamatan Kuala Mandor B, dan Desa Bintang Mas, Kecamatan Rasau Jaya yang terdapat HR. Pengumpulan data dilakukan selama kurang lebih dua bulan yaitu, bulan Juli sampai dengan Agustus 2016.

Objek penelitian adalah masyarakat yang tergabung dalam kelompok tani pengelola HR. Pengumpulan data penelitian menggunakan alat perekam dan kuesioner semi terbuka yang dibagikan kepada responden.
Data yang dianalisis dalam penelitian ini adalah data primer dan data sekunder. Data primer adalah data yang bersumber dari hasil wawancara kepada 25 orang responden dari anggota kelompok tani yang dipilih secara purposive sampling berdasarkan keterlibatannya dalam kegiatan pengelolaan HR di tiap desa. Selanjutnya, data sekunder diperoleh dari instansi atau lembaga yang terkait serta dari literatur yang berhubungan dengan penelitian ini.

Teknik pengambilan data primer dilakukan dengan cara sensus karena responden yang merupakan anggota kelompok tani jumlahnya sedikit. Adapun faktor pengamatan yang dijabarkan dalam pertanyaan kuesioner dapat dilihat pada Tabel 1.

Tabel 1. Variabel dan faktor pengamatan penelitian

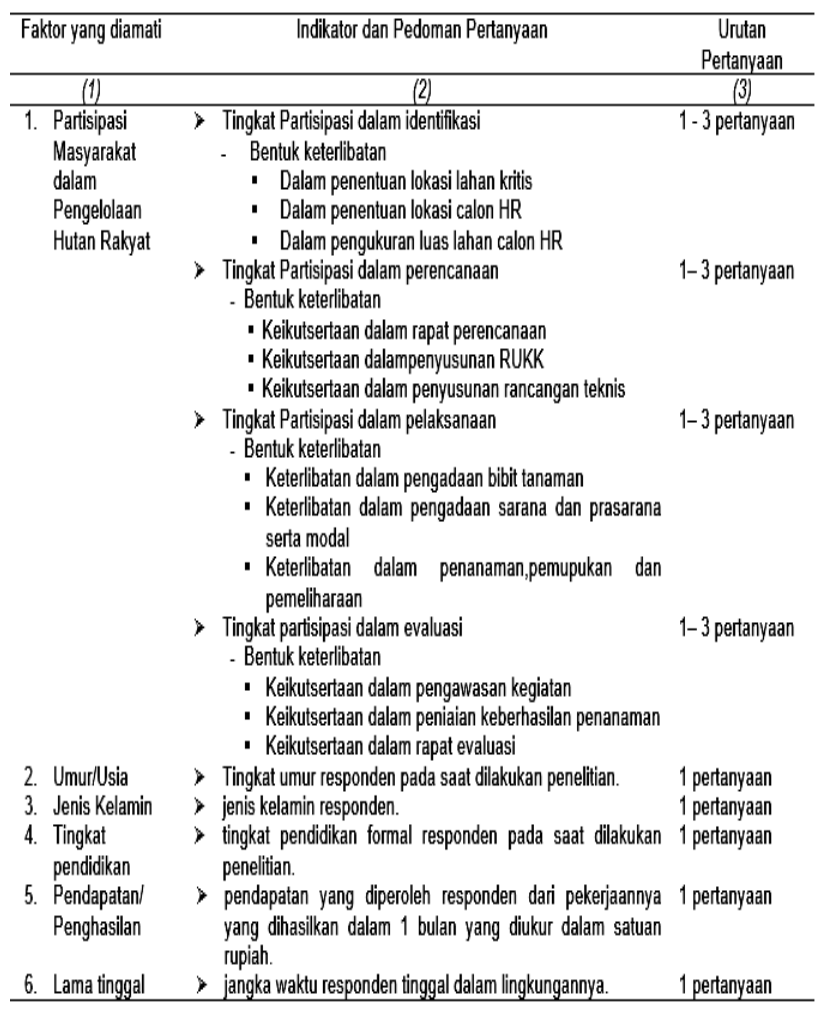

Sumber: penulis (2016)

Data dianalisis secara deskriptif untuk mengetahui tingkat partisipasi masyarakat dalam pembangunan HR dengan menggunakan tabel frekuensi serta penggunaan tabulasi silang untuk mengetahui hubungan antara tingkat 
partisipasi masyarakat dengan faktor individu. Analisis inferensial yang digunakan untuk melihat faktor-faktor yang mempengaruhi tingkat partisipasi masyarakat dalam pengelolaan hutan rakyat menggunakan analisis regresi linier berganda. Analisis tersebut dilakukan dengan bantuan perangkat lunak SPSS versi 18.

\section{HASIL DAN PEMBAHASAN}

\section{A. Analisis Deskriptif}

\section{Karateristik Masyarakat}

\section{a. Tingkat Umur}

Pada analisis peran masyarakat berdasarkan tingkat umur, responden masyarakat di Desa Bintang Mas Kecamatan Rasau Jaya berjumlah 25 responden yang didominasi oleh kelompok umur tua ( $>46$ tahun) yaitu, sebanyak 17 orang atau sebesar $68 \%$. Dengan jumlah responden yang sama masyarakat di Desa Kubu Padi Kecamatan Kuala Mandor B yaitu 25 orang responden, dihasilkan dominasi oleh kelompok umur dewasa (25 - 45 tahun) yaitu sebanyak 12 orang atau sebesar $48 \%$.

Perlu diketahui bahwa Desa Bintang Mas Kecamatan Rasau Jaya merupakan daerah tujuan transmigrasi. Program transmigrasi dimulai sekitar tahun 1980-1990. Mayoritas petanipetani yang aktif dalam kelompok tani di Desa Bintang Mas saat ini adalah masyarakat yang mengikuti program transmigrasi di awal tahun 1990 sehingga responden didominasi oleh kelompok umur tua. Pada kelompok umur dewasa, masyarakat Desa Bintang Mas lebih cenderung bekerja pada sektor non-pertanian, dimana akses untuk mendapatkan lapangan pekerjaan dikota lebih mudah dijangkau sehingga pekerjaan sebagai petani hanya dilakukan sebagai pekerjaan sampingan. Meskipun umur petani hutan lebih banyak di atas 50 tahun, tetapi mereka masih memilih bekerja sebagai petani hutan. Menurut Affandi (2012), keterlibatan masyarakat tersebut berhubungan dengan tingkat pendidikan dan pendapatan keluarga yang rendah.

Tingkat partisipasi masyarakat pada dua desa didominasi oleh tingkat umur dewasa hingga tua dan cenderung memiliki partisipasi yang sedang. Hal ini dikarenakan faktor umur merupakan faktor yang memengaruhi sikap seseorang terhadap kegiatan-kegiatan kemasyarakatan yang ada. Masyarakat dari kelompok umur menengah ke atas mempunyai keterikatan moral kepada nilai dan norma masyarakat yang lebih mantap dan kecenderungan yang lebih banyak dalam berpartisipasi dibandingkan dengan masyarakat yang berasal dari kelompok umur lainnya.

Desa Kubu Padi merupakan daerah yang sedang berkembang. Responden didominasi oleh kelompok umur dewasa karena kegiatan pembangunan di Desa Kubu Padi Kecamatan Kuala Mandor B lebih banyak diterima dan dilakukan oleh kelompok umur dewasa. Kegiatan pengelolaan lahan pertanian lebih banyak dilakukan oleh generasi kedua di setiap keluarga. Pembukaan lahan baru untuk pertanian dilakukan oleh kelompok umur dewasa. Selain itu, akses menuju kota yang jauh menyebabkan banyaknya masyarakat usia dewasa yang memilih menjadi petani di desa daripada mencari pekerjan di kota.

\section{b. Jenis Kelamin}

Masyarakat pada lokus penelitian didominasi oleh yang berjenis kelamin laki-laki. Di Desa Bintang Mas terdapat laki-laki sebanyak $84 \%$ sedangkan di 
Desa Kubu sebanyak 76\%. Dengan demikian, peran pengambilan keputusan produktif untuk bekerja di HR masih didominasi oleh laki-laki dibandingkan dengan perempuan, atau berdasarkan kesepakatan bersama antara suami dan istri. Pihak perempuan atau istri berperan penuh dalam hal keputusan reproduktif rumah tangga misalnya, penentuan menu makanan, uang belanja, dan perabotan rumah tangga. Hasil penelitian ini serupa dengan hasil penelitian tentang pengelolaan agroforestri yang dilakukan oleh Hafizianor dan Hafizah (2016).

Tingkat partisipasi di kedua desa didominasi oleh yang berjenis kelamin laki-laki dengan tingkat partisipasi sedang hingga tinggi. Meskipun demikian, semakin lama nilai partisipasi perempuan mulai diperhitungkan dengan adanya pendidikan bagi perempuan serta gerakan emansipasi perempuan. Namun, persepsi terhadap jenis kelamin yang berkembang di masyarakat masih menganggap tugas perempuan hanyalah di dapur. Ini berarti bahwa dalam masyarakat, peranan perempuan yang paling utama adalah mengurus rumah tangga. Berdasarkan pendapat Manulang (1999), hal ini terjadi karena adanya stratifikasi sosial dalam masyarakat yang membedakan kedudukan laki-laki dan perempuan pada jenis kelamin yang berbeda. Padahal, menurut Eneji, dkk (2015), secara pengetahuan, perempuan sebenarnya tidak kalah dengan lakilaki.

\section{c. Tingkat Pendidikan}

Masyarakat dari kedua lokasi penelitian didominasi oleh kategori tingkat pendidikan rendah (tidak sekolah sampai dengan Tamat SD) sebesar $40 \%$ di desa Bintang Mas dan
36\% di Desa Kubu Padi. Yang berpendidikan tinggi (tamat SMA - PT) sebanyak $48 \%$ di Desa Bintang Mas dan $36 \%$ di Desa Kubu Padi. Hal ini dikarenakan anggota kelompok tani pada kedua desa ini bervariasi antara umur tua dan dewasa dimana pada umur dewasa sudah lebih mudah untuk memperoleh pendidikan yang lebih tinggi. Selain itu, akses dari desa menuju kota kecamatan dimana terdapat sarana pendidikan yang lebih tinggi mudah untuk dijangkau. Tingkat pendidikan tinggi tidak selalu berpengaruh terhadap partisipasi pengelolaan hutan (Jallah, dkk, 2019). Keterlibatan masyarakat dalam pengelolaan HR ternyata dilakukan oleh masyarakat yang pendidikannya rendah dan sedang. Ini patut diduga bahwa masyarakat yang lulusan pendidikan tinggi lebih memilih pekerjaan lain di perkotaan.

Tingkat pendidikan responden di Desa Bintang Mas didominasi oleh yang tingkat pendidikanmya tinggi, namun partisipasinya rendah, sedangkan resonden di Desa Kubu Padi didominasi oleh yang tingkat pendidikannya rendah dengan tingkat partisipasi sedang. Ini dikarenakan responden yang memiliki tingkat pendidikan tinggi cenderung untuk bekerja pada sektor lain seperti pegawai atau karyawan.

\section{d. Tingkat Penghasilan}

Masyarakat dari kedua desa didominasi oleh kelompok kategori berpenghasilan rendah. Sebanyak $56 \%$ responden di Desa Bintang Mas dan $76 \%$ dari Desa Kubu Padi memiliki pendapatan pendapatan kurang dari Rp. 1.500.000,00/bulan. Penyebabnya adalah pendapatan utama masyarakat di kedua lokasi ini sebagai petani. Hasil pertanian yang didapat petani sebagian untuk kebutuhan sehari-hari dan sebagian lagi untuk dijual. Dengan 
adanya $\mathrm{HR}$, mereka diharapkan dapat meningkatkan penghasilan masyarakat di kedua desa.

Berdasarkan hasil survey, responden dari Desa Bintang Mas didominasi oleh yang berpenghasilan rendah dengan tingkat partisipasi rendah, sedangkan di Desa Kubu Padi responden didominasi oleh yang tingkat penghasilannya rendah dan cenderung memiliki partisipasi sedang. Perbedaan yang terjadi disebabkan oleh sumber penghasilan di Desa Bintang Mas yang lebih bervariasi, sedangkan masyarakat di Desa Kubu Padi cenderung menaruh harapan akan mendapat tambahan penghasilan yang layak dari pengelolaan HR. Hasil penelitian ini bersesuaian dengan hasil penelitian Susanto dan Sulasno (2017) di HR Kecamatan Gemarang Madiun. Pada lahan hak milik, masyarakat menggunakan sistem agroforestri yang kemudian memberikan hasil yang positif terhadap peningkatan perekonomian masyarakat dengan pengembalian modal di bawah lima tahun. Hal tersebut berlaku di semua luasan lahan milik 0,25 hektar hingga lebih dari 1 hektar.

\section{e. Lama Tinggal}

Masyarakat dari kedua lokasi penelitian didominasi oleh kelompok yang dikategorikan sudah lama tinggal, (lebih dari 20 tahun). Di desa Bintang Mas sebanyak 60\% dan Desa Kubu Padi sebanyak $76 \%$. Responden dari Desa Bintang Mas, Kecamatan Rasau Jaya merupakan masyarakat yang ikut program transmigrasi tahap pertama. Dengan demikian, mereka sudah lama menetap di desa tersebut, sedangkan responden dari Desa Kubu Padi, Kecamatan Kuala Mandor B merupakan penduduk asli daerah tersebut. Oleh karena itu, mereka telah menetap disana secara turun temurun.
Masyarakat dari kedua desa yang sudah lama tinggal cenderung memiliki partisipasi sedang hingga tinggi. Masyarakat Desa Bintang Mas menunjukkan partisipasi tinggi pada kelompok yang tinggal lebih dari 20 tahun karena mayoritas mereka adalah peserta transmigrasi tahap pertama sehingga bertani adalah pekerjaan utama mereka. Pada masyarakat Desa Kubu Padi partisipasinya sedang pada kelompok lama tinggal lebih dari 20 tahun karena selain bertani mereka juga mempunyai pekerjaan lain. Menurut Achmad, dkk (2015), masyarakat yang telah lama menetap akan memiliki pemahaman tentang karakteristik lahan dan mempermudah dalam pengelolaan yang dilakukan. Hal tersebut juga memberi peluang kepada petani dalam menemukan teknologi pengembangan $\mathrm{HR}$ yang sesuai di daerah itu.

\section{Karakteristik HR \\ a. Karakteristik HR Berdasarkan Status Lahan}

HR yang terdapat di Desa Bintang Mas, Kecamatan Rasau Jaya didominasi oleh kategori milik pribadi. Namun, sebagian besar dari lahan milik pribadi ini adalah kepunyaan orang lain yang bukan dari anggota kelompok tani. Anggota kelompok tani ini diberikan ijin untuk menanami lahan tersebut. ljin yang diberikan oleh pemilik lahan hanya berupa ijin lisan tanpa adanya perjanjian tertulis. Hal ini dikarenakan lahan milik pribadi dari setiap responden digunakan untuk bertani atau sawah yang luasnya hanya cukup untuk bertani sehingga ketika mereka mendapat bantuan pembangunan HR mereka melakukannya di lahan milik pribadi yang diijinkan untuk ditanami. Pada lahan tersebut masing-masing anggota kelompok menanam pada areal-areal tertentu yang menjadi 
bagiannya untuk ditanami. Namun, lahan tersebut bukan lahan miliknya. HR yang terdapat di Desa Kubu Padi Kecamatan Kuala Mandor B juga didominasi oleh kategori milik pribadi.

Lahan hutan rakyat merupakan milik anggota kelompok tani. Hal ini dikarenakan setiap responden memiliki lahan pertanian yang cukup luas sehingga masing-masing anggota kelompok dapat menanam pohon dari kegiatan pembangunan HR pada lahan milik pribadi. Selain itu, masyarakat anggota kelompok tani juga memperhitungkan letak tanah milik mereka untuk dijadikan lokasi pembangunan $\mathrm{HR}$.

Masyarakat Desa Bintang Mas memiliki lahan pribadi yang dekat dengan akses jalan sehingga mereka lebih memilih untuk menanami lahan pribadi dengan tanaman semusim sehingga mudah dalam aspek pemasaran. Masyarakat Desa Kubu Padi memiliki lahan pribadi yang tersebar, tidak hanya dekat dengan akses jalan sehingga mereka dapat memanfaatkan lahan milik pribadi lebih leluasa untuk ditanami dengan tanaman tahunan tanpa khawatir terjadinya konflik dengan pihak lain (De Royer, dkk, 2018).

Status lahan hak milik membuat masyarakat tidak ragu untuk mengusahakannya menjadi HR. Dicontohkan dalam pengusahaan HR di Kabupaten Gunung Kidul meskipun lahan yang dimiliki sempit, masyarakat menerapkan strategi diversifikasi jenis tanaman penyusun HR untuk meningkatkan hasil dan menyebar resiko pengelolaan. Sehingga tercatat kontribusi HR terhadap pendapatan petani di Kabupaten Gunungkidul yaitu, 13-40\% (Oktalina, dkk, 2015).

\section{b. Karakteristik HR Berdasarkan Teknik Penanaman}

Teknik penanaman hutan rakyat di dua desa seluruhnya menggunakan sistem jalur. Teknik penanaman ini sudah ditentukan oleh instansi terkait. Teknik penanaman harus mengikuti rencana penanaman yang dibuat oleh instansi tersebut sehingga petani hanya mengikuti arahan dari petugas. Petugas dari instansi terkait telah melakukan survei lapangan untuk melihat kondisi dari lahan masyarakat yang akan dijadikan hutan rakyat.

Berdasarkan pengamatan di lapangan diketahui bahwa lokasi HR yang berada di kedua lokasi berada pada tingkat kelerengan datar hingga landai. Jenis tanah gambut yang jauh dari sungai sehingga lokasi ini termasuk tidak peka terhadap erosi tanah. Teknik penanaman dengan sistem jalur sangat sesuai untuk lahan dengan tingkat kelerengan datar sampai dengan landai dan tanah tidak peka terhadap erosi. Teknik ini dapat berfungsi juga sebagai pengendalian daur air (Suryatmojo, 2018).

\section{c. Karakteristik HR Berdasarkan Bentuknya}

Karakteristik HR Desa Bintang Mas adalah sistem hutan rakyat monokultur, sedangkan Desa Kubu Padi sistem hutan rakyat agroforestry. Masyarakat Desa Bintang Mas menanam tanaman kayu pada lahan milik orang lain yang memberikan ijin untuk menanam di lahannya, bukan di lahan miliknya. Oleh karena itu, mereka tidak mencampur dengan tanaman semusim. Masyarakat Desa Kubu Padi menanam tanaman kayu di lahan milik pribadi dimana lahan tersebut juga mereka tanami dengan tanaman semusim seperti terong, cabe, serta padi. 
HR yang berbentuk monokultur dan agroforestry mempunyai kelebihan masing-masing. Kelebihan bentuk HR monokultur yaitu, dapat mengurangi persaingan tanaman pokok dengan tanaman lain karena pada lahan tersebut hanya terdapat satu tanaman saja. Fokus kegiatan pemeliharaan hanya pada satu tanaman pokok itu saja. Bentuk HR agroforestri mempunyai kelebihan yaitu, dapat meningkatkan efisiensi penggunaan lahan yang dapat memberikan penghasilan tambahan bagi pemilik lahan karena di lahan tersebut terdapat berbagai macam jenis tanaman yang dapat dimanfaatkan selain tanaman pokok. Masyarakat menganggap pola agroforesti dapat memberikan banyak manfaat, baik secara ekonomi maupun ekologis (Hudiyani, dkk, 2017).

\section{d. Karakteristik HR Berdasarkan Jenis Tanaman}

Jenis tanaman yang ditanam pada dua desa didominasi oleh tanaman cepat tumbuh (fast growing). Hal ini dikarenakan informasi yang diterima petani melalui kisah sukses petani lainnya yang telah berhasil menanam tanaman tersebut. Jenis tanaman yang dipilih oleh masyarakat merupakan jenis tanaman cepat tumbuh dan telah memiliki pangsa pasar di daerah mereka yang mempunyai harga jual tinggi (mudah dipasarkan). Selain untuk dijual, hasil dari tanaman hutan rakyat dapat juga digunakan untuk keperluan sendiri dalam pemenuhan bahan baku papan.

Jenis - jenis tanaman cepat tumbuh antara lain adalah Sengon (Parasirienthes falcataria), Akasia (Acacia mangium), Ekaliptus (Eucalyptus urophylaa), Ficus (Ficus sp), dan Jabon (Anthocephalus cadamba). Jenis tanaman-tanaman tersebut merupakan tanaman cepat tumbuh karena mempunyai daur 19 | Jurnal Borneo Akcaya tebang atau waktu panen kurang dari 10 tahun. Tanaman tersebut juga merupakan tanaman yang telah memiliki pangsa pasar tersendiri. Dari hasil wawancara dengan beberapa petani ternyata telah ada beberapa permintaan kayu sengon dan kayu jabon untuk daerah pemasaran di Pulau Jawa. Namun, sangat disayangkan kualitas kayu yang dihasilkan dari HR relatif masih rendah. Ini dipengaruhi oleh perawatan yang diberikan yaitu, belum mengikuti teknik yang benar, seperti yang terjadi pada tanaman sengon (Paraserianthes falcataria) dan sungkai (Peronema canescens) di HR Kabupaten Tabalong Kalimantan Selatan. Tanaman yang tumbuh mengalami banyak percabangan dan bengkok disebabkan jarak tanam dan kombinasi jenis yang tidak tertata. (Wahyudi \& Christopheros, 2018)

Pemerintah dan petani harus menyepakati hal pemilihan jenis tanaman yang ditanam pada lahan $\mathrm{HR}$, dengan mempertimbangkan minat masyarakat, kondisi agroklimat serta permintaan pasar. Semakin tinggi keanekaragaman tanaman komersial yang ditanam di HR, maka berpotensi untuk mendapatkan pendapatan yang lebih besar (Pietersen, dkk, 2018).

Menurut penelitian Fauziyah, dkk (2016) terhadap petani pala yang dikembangkan di HR Kecamatan Somagede, Kabupaten Banyumas, faktor yang mempengaruhi pemilihan jenis yaitu, 1) lahan secara bio fisik sesuai untuk pertumbuhan tanaman, 2) secara sosial dapat diterima oleh masyarakat karena sudah banyak petani yang berhasil sebelumnya, 3) secara ekonomi memiliki harga yang cukup tinggi dan stabil sehingga memberikan tambahan pendapatan, 4) kondisi pemasaran baik buah maupun bibitnya sangat mudah, dan 5) perhatian pemerintah terhadap 
pengembangan jenis tanaman tersebut pada tingkat produksi hingga pengolahan pasca panen.

\section{Partisipasi Masyarakat Dalam Pengelolaan HR}

Partisipasi masyarakat di kedua desa berada pada tingkatan sedang hingga rendah. Masyarakat di Desa Bintang Mas dan Desa Kubu Padi pada dasarnya sudah sangat mengerti dan memahami arti pentingnya keberadaan hutan rakyat bagi peningkatan kesejahteraan mereka. Selain itu, mereka juga sudah mengetahui manfaat ekologi dari keberadaan hutan rakyat bagi lingkungan mereka. Namun, tingkat partisipasi masyarakat di kedua desa tidak berada pada tingkat partisipasi tinggi pada saat penelitian yang disebabkan oleh pembangunan hutan rakyat yang mendapat bantuan dari pemerintah.

Pelaksanaan

kegiatan pembangunan hutan rakyat di kedua desa ini hanya diberdayakan secara intensif dalam kegiatan pelaksanaan penanaman hingga pemeliharaan. Pada tahapan identitifikasi, perencanaan serta evaluasi, masyarakat kurang diberdayakan. Pada tahap tersebut instansi terkait serta pengurus inti dari kelompok yang lebih banyak berperan dalam kegiatan identifikasi, perencanaan hingga kegiatan evaluasi.

Tidak ada perbedaan tingkat partisipasi di kedua desa, antara tingkat rendah, sedang dan tinggi. Hal ini dimungkinkan karena masyarakat yang tergabung dalam kelompok tani pengelola hutan rakyat ini mengelola hutan rakyat karena ada ajakan dari ketua kelompok, sehingga faktor keikutsertaan dalam mengelola hutan rakyat hanya berdasarkan dari ajakan ketua kelompok saja. Partisipasi masyarakat di Desa Kubu Padi didominasi oleh tingkat partisipasi sedang. Hal ini dikarenakan masyarakat hanya berpartisipasi pada saat pelaksanaan kegiatan penanaman saja, sedangkan pada tahap perencanaan dan tahap evaluasi lebih banyak dilaksanakan oleh tim inti kelompok bersama instansi terkait.

Pemerintah daerah membuat suatu program pembangunan hutan rakyat dengan tujuan agar masyarakat dapat merasakan manfaat dari kegiatan tersebut. Berdasarkan hasil wawancara, masyarakat cukup merasakan manfaat dengan adanya program pembangunan HR yang diberikan oleh pemerintah daerah. Manfaat yang dirasakan oleh masyarakat dalam pembangunan HR ini terutama dalam peningkatan kesejahteraan serta pengetahuan akan pentingnya hutan dalam menopang kehidupan mereka.

$\begin{array}{lll}\text { Meskipun masyarakat telah } \\ \text { merasakan } & \text { manfaat }\end{array}$
pembangunan $H R$ namun partisipasi mereka masih rendah. Hal ini dikarenakan program tersebut berlangsung relatif singkat. Selain itu, komunikasi yang terjadi antara instansi terkait dengan anggota kelompok terbatas hanya pada saat sosialisasi dan pemeriksaan pekerjaan yang hanya berjalan satu arah. Menrut, Wekesa (2017), partisipasi masyarakat dapat ditingkatkan dengan adanya nilai tambah dari hasil HR yang diperoleh. Untuk itu pemberdayaan masyarakat masih perlu ditingkatkan melalui kegiatan workshop, pelatihan, terkait manajemen pemasaran maupun teknologi yang bisa diterapkan di HR.

Analisis partisipasi masyarakat menggunakan kriteria Arnstein menunjukkan bahwa skor kedua desa berada pada tingkat 4 (empat) yaitu, tingkat konsultasi (Arnstein, 1969). Sesuai dengan jumlah skor partisipasi 
masing-masing responden pada kedua desa yang berada pada tingkat sedang hingga rendah. Ini membuktikan bahwa masyarakat di kedua desa tersebut dalam melaksanakan pembangunan HR masih berdasarkan atas arahan dari pemerintah melalui instansi terkait. Pelibatan masyarakat dalam kegiatan pembangunan hanya pada saat tahap pelaksanaan dan pemeliharaan. Pada tahap-tahap identifikasi, perencanaan, hingga evaluasi lebih banyak dilaksanakan oleh instansi terkait. Ini berarti bahwa partisipasi masyarakat di kedua desa berada pada tingkat tokenisme (tokenism) yaitu, dimana masyarakat berhak untuk mendengarkan dan didengarkan, tetapi tidak mempunyai kekuasaan untuk memastikan bahwa pandangan mereka diperhatikan (Ocloo \& Matthews, 2016). Pemegang kekuasaan hanya meminta dan mendengarkan pendapat dari masyarakat dalam kegiatan pembangunan hutan rakyat. Masyarakat dianggap telah berpartipasi dilihat dari kehadiran dalam kegiatan penanaman saja. Tetapi, ide-ide serta masukan dari masyarakat hanya didengar, tetapi belum tentu dilaksanakan. Hal ini sudah dianggap oleh pemegang kekuasaan kalau mereka telah melibatkan masyarakat dalam partisipasi kegiatan kehutanan. Partisipasi masyarakat dapat menjadi alat untuk memperoleh informasi mengenai kondisi, kebutuhan, dan sikap masyarakat setempat.

Tahap partisipasi pada tangga konsultasi menggambarkan bahwa masyarakat di kedua desa telah ikut berpartisipasi melalui pertemuanpertemuan yang diadakan oleh instansi terkait. Hasil wawancara menunjukkan bahwa setiap kali dilakukan pertemuan yang dilakukan oleh instansi terkait, kelompok tani berusaha ikut serta dengan mengirimkan utusan atau perwakilan dari kelompok mereka untuk menghadiri pertemuan yang diadakan. Pertemuan yang diadakan oleh instansi terkait diadakan di ibukota kabupaten, sehingga hanya utusan atau perwakilan dari kelompok yang dapat mengikuti kegiatan tersebut. Utusan atau perwakilan dari kelompok tersebut menyampaikan aspirasi dari kelompoknya. Instansi terkait menampung semua aspirasi dari kelompok dan akan diakomodir sesuai dengan rencana kerja yang telah dibuat.

Aspirasi kelompok yang telah disampaikan dapat diakomodir atau dilaksanakan oleh instansi terkait apabila sesuai dengan rencana kerja yang telah dibuat. Apabila aspirasi tersebut tidak sesuai dengan rencana yang telah dibuat, maka aspirasi itu hanya sekedar ditampung tanpa ada pelaksanaannya. Tahapan konsultasi pada tangga partisipasi menyebabkan komunikasi yang dibangun bersifat dua arah, tapi masih bersifat partisipasi yang ritual. Sudah ada penyaringan partisipasi, telah ada aturan pengajuan usul, telah ada harapan bahwa aspirasi masyarakat akan didengar, tetapi belum ada jaminan bahwa aspirasi tersebut akan dilaksanakan. Ini menandakan bahwa partisipasi yang terjadi adalah partisipasi semu. Partisipasi semu dapat mengakibatkan kegiatan pembangunan HR yang dilaksanakan tidak berjalan sesuai dengan rencana yang telah ditetapkan sehingga tujuan akhir dari kegiatan pembangunan hutan rakyat tersebut tidak tercapai.

Tahapan konsultasi masuk dalam tingkatan tokenisme yang dapat diartikan bahwa kegiatan penyampaian aspirasi disini dapat diartikan sebagai kebijakan sekedarnya atau tindakan simbolis dalam pencapaian suatu tujuan. Jadi kegiatan partisipasi disini

21 Jurnal Borneo Akcaya 
hanya sekedar membuat kewajiban saja dan bukan usaha sungguhsungguh untuk melibatkan masyarakat secara nyata. Semua aspirasi yang disampaikan dalam dialog seperti saran, masukan, dan kritik dapat disampaikan oleh masyarakat tanpa merasa dihalangi bahkan diberi ruangan sebesar-besarnya dalam berpartisipasi. Namun, keputusan akhir tetap berada di tangan pemerintah daerah yang dalam hal ini instansi terkait yang telah disesuaikan dengan rencana kerja.

Masih terjadi hambatan dimana masyarakat mengharapkan keterlibatan dan manfaat yang lebih dalam pengelolaan hutan rakyat. Hal ini belum dapat diakomodir sepenuhnya oleh pemerintah. Dampaknya adalah partisipasi masyarakat dalam pengelolaan HR menjadi menurun (Younis, dkk, 2018).

\section{Faktor Eksternal Yang Mempengaruhi Masyarakat Dalam Mengelola HR}

\section{a. Penyuluhan Kehutanan}

Hasil pengamatan dan wawancara dengan anggota kelompok tani di kedua lokasi penelitian menunjukkan bahwa keterlibatan mereka pada kegiatan pembangunan HR diawali adanya penyuluhan kehutanan yang dilakukan oleh instansi terkait. Masyarakat mengetahui adanya kegiatan pembangunan hutan rakyat dari penyuluhan yang diberikan oleh petugas dari instansi terkait. Ini berarti bahwa penyuluhan kehutanan merupakan salah satu faktor atas keterlibatan masyarakat berpartisipasi dalam pembangunan hutan rakyat.

Penyuluhan terbukti memberikan dampak positif terhadap peningkatan pengetahuan dan kesediaan petani sebagai pengelola HR. Menurut hasil penelitian Diniyati \& Ahmad (2016) meskipun kegiatan penyuluhan dengan metode yang konvesional dalam bentuk ceramah dan diskusi menunjukkan peningkatan pengetahuan sebesar $50 \%$ pada petani di HR di Kabupaten Ciamis dan Tasikmalaya.

Menurut informasi yang diperoleh dari instansi terkait, kegiatan penyuluhan kehutanan hanya dilakukan pada saat adanya kegiatan sosialisasi yang diadakan oleh Dinas Perkebunan, Kehutanan dan Pertambangan Kabupaten Kubu Raya. Selain itu, penyuluhan diberikan pada saat petugas turun ke lapangan untuk melakukan koordinasi dengan kelompok, tetapi yang melakukan penyuluhan bukan petugas penyuluh kehutanan, tetapi tenaga teknis kehutanan yang diberi tugas untuk memberikan informasi kepada masyarakat tentang kegiatan pembangunan HR. Hal ini dikarenakan keterbatasan jumlah tenaga penyuluh kehutanan yang ada di Kabupaten Kubu Raya serta penyuluh kehutanan berada pada instansi yang berbeda.

Selain kegiatan penyuluhan kehutanan, pelibatan masyarakat dalam pembangunan HR juga membutuhkan akses informasi tentang kegiatan tersebut. Akses informasi yang baik diharapkan dapat membuat masyarakat yang terlibat didalamnya akan lebih aktif mengikuti kegiatan yang sedang dilaksanakan. Apabila pengetahuan masyarakat tentang pembangunan HR sangat baik, diharapkan kegiatan pembangunan hutan rakyat dapat berjalan dengan lancar.

Berdasarkan pengamatan dan wawancara dengan anggota kelompok tani dari kedua desa, akses informasi yang mereka dapatkan tentang pembangunan HR tidaklah sulit. Perkembangan teknologi yang telah 
menyentuh sampai di daerah pedesaan merupakan salah satu faktor penyebab mudahnya masyarakat mengetahui tentang kegiatan pembangunan HR. Mereka memperoleh informasi melalui siaran radio, televisi, bahkan melalui internet. Selain itu cerita sukses yang beredar dari mulut ke mulut tentang manfaat HR juga menjadi alasan masyarakat di kedua desa ikut berpartisipasi dalam kegiatan pembangunan hutan rakyat. Kedepannya, selain perbaikan akses informasi, akses modal juga perlu diperhatikan dalam usaha pemberdayaan dan pembangunan kapasitas masyarakat di desa (Reski, dkk, 2017)

\section{b. Kelompok Tani Hutan (KTH)}

Keberadaan sebuah Kelompok Tani Hutan (KTH) dalam kegiatan rehabilitasi hutan dan lahan ( $\mathrm{RHL}$ ) sangat diperlukan. Kegiatan RHL salah satu programnya adalah HR. Kegiatan ini dilakukan pada lahan milik masyarakat, sehingga keberadaan kelompok tani hutan tidak dapat dilepaskan dari kegiatan $\mathrm{RHL}$ yang akan dilaksanakan. Selain itu program pembangunan HR yang diberikan oleh pemerintah daerah kepada masyarakat harus melalui suatu kelompok sebagai sarana untuk menyampaikan program dan tujuan kegiatan RHL. Keberadaan KTH merupakan sarana bagi anggotanya untuk menyampaikan aspirasi, sehingga dapat dijadikan tolak ukur partisipasi anggota dalam suatu kegiatan yang dilaksanakan. KTH itu sendiri dibentuk berdasarkan kerelaan masyarakat untuk ikut bergabung. Eksistensi kelompok tani ini dapat menjadi ukuran keberhasilan pembangunan HR karena anggota kelompok tani ini menjadi pelaksana kegiatan di lapangan.

Merujuk kepada hasil wawancara
dan pengamatan di lapangan,
$23 \mid$ Jurnal Borneo Akcaya

kelompok tani di kedua desa terbentuk pada saat diperoleh informasi bahwa akan dilaksanakan kegiatan $\mathrm{RHL}$ di desa mereka. Kelompok tani ini belum terbentuk sebelumnya. Ketika ada petugas kehutanan yang melakukan sosialisasi bahwa akan diadakan kegiatan $\mathrm{RHL}$ di daerah tersebut, sekelompok petani langsung bermusyawarah membentuk sebuah kelompok. Sebagian besar masyarakat menjadi anggota karena ajakan ketua kelompok tani. Selanjutnya, sesuai dengan informasi yang diperoleh dari instansi terkait, petugas mendampingi sekelompok masyarakat untuk membentuk kelompok tani. Pertama kali yang dibentuk adalah tim inti yang terdiri dari ketua, wakil ketua, sekretaris dan bendahara. Selanjutnya tim inti ini mengajak masyarakat untuk ikut menjadi anggota. Setelah didapatkan jumlah anggota kelompok tani yang sesuai dengan persyaratan, kemudian dilaksanakan musyawarah kelompok untuk membuat aturan kelompok tersebut.

Menurut Rimbawati, dkk. (2018), proses mempertahankan eksistensi KTH akan mengalami dinamika. KTH perlu mengantispasi kemunduran dalam hal arah tujuan, fungsi tugas dan keefektifan kelompok, struktur, pembinaan dan pengembangan, kekompakan, suasana dan tekanan kelompok. Faktor penyebab kemunduran tersebut terkait dengan rendahnya tingkatan peran penyuluh, ketidaksesuaian materi penyuluhan, dan kurangnya kemitraan.

\section{c. Peluang Pasar}

Salah satu tujuan pemerintah mengembangkan hutan rakyat adalah untuk meningkatkan pendapatan masyarakat yang berada di dalam dan di sekitar hutan yang diperoleh dari pemasaran hasil hutan rakyat berupa kayu dan non kayu. Titik berat dalam 
pembangunan HR yang dilakukan oleh pemerintah adalah hasil hutan kayu. Peluang pasar yang baik terhadap hasil hutan rakyat berupa kayu diharapkan dapat menjadi daya tarik tersendiri bagi masyarakat untuk ikut berpartisipasi dalam pembangunan HR.

Berdasarkan hasil pengamatan dan wawancara dengan anggota kelompok tani di kedua desa, ternyata peluang pasar dari hasil hutan rakyat ini sudah cukup baik. Diketahui sudah ada pembeli yang turun langsung ke desa untuk mencari kayu hasil tanaman rakyat dalam skala yang cukup besar. Namun, karena masyarakat di kedua desa baru memulai untuk membangun hutan rakyat, maka kayu-kayu yang dijual adalah hasil tanaman yang tumbuh sendiri di lahan mereka yang jumlahnya tidak begitu besar. Peluang pasar ini menjadi salah satu alasan bagi masyarakat untuk ikut berpartisipasi dalam pembangunan hutan rakyat.

Menurut informasi yang diperoleh dari pembeli yang turun langsung ke desa, pemasaran kayu rakyat ini untuk memenuhi permintaan kayu dari Pulau Jawa, terutama dari daerah Semarang dan Boyolali. Jenis kayu yang diminati yaitu jenis sengon, jabon dan akasia. Peruntukan kayu rakyat ini untuk memenuhi bahan baku mebel, kayu lapis serta kayu pertukangan. Harga dari setiap jenis kayu berbeda sesuai dengan ukuran diameter. Setiap satu bulan sekali pembeli dari Pulau Jawa turun langsung ke desa-desa untuk membeli kayu rakyat dengan harapan harga tetap stabil antara penjual dan pembeli.

Hasil penelitian Abdullah (2019) menunjukkan bahwa jika pangsa pasar kayu tidak ada pesaing, maka tutupan hutan cenderung stabil. Sebaliknya jika ada pesaing, maka masyarakat akan cenderung mengonversi lahan hutannya untuk peruntukan lahan lainnya. Pada kondisi ini, pemerintah harus mengambil posisi dalam bentuk mengeluarkan kebijakan perdagangan kayu. Ada dua strategi yang ditawarkan yakni, penetapan harga dasar kayu dan fasilitasi kartel perdagangan kayu. Hasil simulasi menunjukkan bahwa harga dasar kayu yang bersifat statis akan menjadi jawaban untuk menahan konversi hutan, namun tidak untuk jangka panjang. Sementara strategi kartel perdagangan dengan kelembagaan yang solid akan membantu meningkatkan produktivitas petani hutan rakyat dan mempertahankan kelestarian hutan dengan menghambat konversi hutan dan meningkatkan tutupan lahan oleh hutan

Faktor-faktor eksternal yang diamati dalam penelitian ini yang dianggap dapat mempengaruhi partisipasi masyarakat dalam pembangunan HR adalah faktor penyuluhan kehutanan, kelompok tani hutan, dan akses pasar. Dari ketiga faktor eksternal tersebut faktor penyuluhan kehutanan dan peluang pasar berpengaruh terhadap partsipasi masyarakat. Sedangkan faktor keberadaan kelompok tani hutan tidak berpengaruh terhadap partisipasi masyarakat. Hal ini diduga karena informasi yang disampaikan oleh petugas saat melakukan sosialisasi membuat masyarakat tertarik untuk ikut serta dalam kegiatan pembangunan hutan rakyat. Selain itu informasi yang mudah diperoleh, yang memberikan gambaran tentang kisah sukses seseorang dalam mengembangkan tanaman hutan juga membuat masyarakat tertarik ikut dalam kegiatan tersebut.

Bahwa keberadaan kelompok tani hutan tidak berpengaruh terhadap partisipasi masyarakat diduga karena 
keberadaan kelompok tani ini terbentuk pada saat program kegiatan ini akan dilaksanakan, bukan terbentuk sebelumnya. Dengan demikian, keterikatan antar anggota kelompok tidak begitu mendalam. Selain itu keberadaan kelompok tani hutan ini tidak dapat menampung ataupun menyampaikan aspirasi anggotanya kepada pembuat program kegiatan; kelompok tani hanya dianggap sebagai jalan untuk mendapatkan bantuan saja.

Kelompok tani yang merupakan lembaga bagi petani yang tergabung didalamnya tidak mampu berperan sebagai sebuah lembaga. Penyebabnya adalah terbentuknya kelompok tani ini karena akan dilaksanakannnya program pemerintah yang mengharuskan bahwa setiap masyarakat penerima bantuan harus merupakan suatu lembaga yang berbadan hukum. Kelompok tani ini dibentuk atas pendampingan dari petugas, bukan merupakan kelompok tani yang sudah berdiri sebelumnya.

Faktor eksternal yang berpengaruh dalam partisipasi masyarakat dapat menjadi suatu metoda untuk meningkatkan partisipasi masyarakat dalam pembangunan hutan rakyat. Kegiatan penyuluhan kehutanan yang intensif dapat meningkatkan pengetahuan masyarakat yang tergabung dalam kelompok tani hutan sehingga kesadaran untuk tetap berpartisipasi dalam program kegiatan tetap tinggi sesuai dengan tujuan dari kegiatan. Selain itu perlu adanya suatu kejelasan harga pasar tentang kayu sengon yang disosialisasikan kepada masyarakat agar mereka dapat meningatkan minat masyarakat untuk ikut serta dalam pembangunan hutan rakyat.

\section{B. Analisis Inferensial}

\section{Uji Koefisien Regresi Secara Bersama-Sama (Uji F) dan Uji Regresi Parsial (Uji-t)}

Hasil uji regresi secara bersamasama (uji-F) Desa Bintang Mas dapat dilihat di Gambar 2.

\begin{tabular}{|c|c|c|c|c|c|c|}
\hline \multicolumn{7}{|c|}{ ANOVA $^{b}$} \\
\hline Model & & Sum of Squares & Df & Mean Square & $\mathrm{F}$ & Sig. \\
\hline 1 & Regression & 431,278 & 5 & 86,256 & .578 &, $716^{\mathrm{a}}$ \\
\hline & Residual & 2834,722 & 19 & 149,196 & & \\
\hline & Total & 3266,000 & 24 & & & \\
\hline
\end{tabular}

Gambar 2. Hasil uji koefisien regresi secara bersamasama (Uji F) Desa Bintang Mas

Nilai $F$ hitung sebesar 0,578 dan nilai sig(p-value) adalah 0,716. Begitu juga dengan Desa Lubuk Padi nilai $F$ hitungnya adalah 1,643 dan nilai sig( $p$ value) adalah 0,197. Hasil hitung ini dapat dilihat pada Gambar 3.

\begin{tabular}{|c|c|c|c|c|c|c|}
\hline \multicolumn{7}{|c|}{ ANOVA $^{\mathrm{a}}$} \\
\hline Model & & Sum of Squares & df & Mean Square & $\mathrm{F}$ & Sig. \\
\hline 1 & Regression & 1256,720 & 5 & 251,344 & 1,643 &, $197^{\mathrm{b}}$ \\
\hline & Residual & 2907,280 & 19 & 153,015 & & \\
\hline & Total & 4164,000 . & 24 & & & \\
\hline
\end{tabular}

Gambar 3. Hasil uji koefisien regresi secara bersamasama (Uji F) Desa Kubu Padi

Ini berarti bahwa semua variabel independen yaitu, umur, jenis kelamin, pendidikan, pendapatan, lama tinggal, secara bersama-sama tidak berpengaruh secara nyata terhadap partisipasi masyarakat dalam pembangunan hutan rakyat di kedua desa.

Hasil Uji secara parsial (uji-t) menunjukkan bahwa hasil masingmasing variabel umur, jenis kelamin, tingkat pendidikan, tingkat pendapatan dan lama tinggal tidak berpengaruh nyata pada terhadap pembangunan hutan rakyat di kedua desa.

Pengaruh faktor - faktor internal terhadap partisipasi masyarakat di Desa Bintang Mas Kecamatan Rasau 
Jaya dan di Desa Kubu Padi Kecamatan Kuala Mandor B Kabupaten Kubu Raya tergolong rendah. Menurut penelitian Kartodiharjo dan Nugroho (2016) di Kabupaten Muna, penyebab rendahnya partisipasi masyarakat bersumber dari sektor kebijakan dimana kebijakan tentang $\mathrm{HR}$ masih kurang dipahami oleh pemerintah dan kurangnya respon untuk pengimplementasian oleh pelaksana kebijakan (Bupati, Pegawai Dinas Kehutanan, Penyuluh Kehutanan) dan masyarakat yang menjadi subyek kebijakan.

Hasil analisa inferensial terhadap lima faktor internal masyarakat pada kedua desa yaitu umur, jenis kelamin, pendidikan, pendapatan atau penghasilan, dan lama tinggal menunjukkan bahwa ternyata tidak ada hubungan antara faktor-faktor internal tersebut dengan partisipasi masyarakat dalam pembangunan HR. Hasil ini muncul karena dalam pelaksanaan kegiatan pembangunan HR yang merupakan program dari pemerintah daerah, masyarakat hanya menjadi pelaksana di lapangan. Tahapan pekerjaan dalam pembangunan $\mathrm{HR}$ telah ditentukan oleh pemerintah daerah melalui instansi terkait. Dengan demikian, masyarakat hanya berpartisipasi ketika ada arahan untuk melaksanakan kegiatan tersebut. Hal ini juga dapat dijelaskan dari tingkat partsipasi masyarakat yang menduduki tangga keempat dari teori Arnstein yaitu, tangga konsultasi yang masuk dalam tahapan tokenisme.

Untuk mencapai tujuan program pembangunan HR ini, pemerintah perlu memperhatikan faktor internal yang dipadukan dengan faktor eksternal dari masyarakat. Apabila salah satu faktor ini diabaikan, maka tujuan dari program yang dijalankan tidak tercapai sesuai harapan. Tingkat partisipasi masyarakat yang cenderung rendah dalam kegiatan pembangunan HR di Kabupaten Kubu Raya serta tidak adanya pengaruh yang signifikan dari faktor internal menunjukkan bahwa kegiatan tersebut telah mengabaikan salah satu faktor penting dalam pembangunan yang bersifat partisipatif yaitu faktor dari dalam masyarakat sendiri. Kegiatan pembangunan HR ini hanya dilaksanakan dalam rangka pencapaian target program kegiatan dari pemerintah. Seharusnya sebelum pelaksanaan kegiatan dilakukan, perlu adanya kajian yang mendalam tentang masalah-masalah teknis di lapangan seperti keadaan masyarakat penerima, kondisi lahan, serta faktor pendukung lainnya.

Pelaksanaan

kegiatan pembangunan HR di Kabupaten Kubu Raya yang bersifat partisipatif oleh pemerintah daerah melalui instansi terkait adalah hanya kegiatan penyuluhan ataupun sosialisasi yang sudah dianggap menjalankan program partisipatif. Hal ini sesuai dengan tangga keempat Arnstein yaitu, tangga konsultasi dimana pemegang kekuasaan memberi peluang kepada masyarakat untuk berpendapat tetapi tidak ada jaminan bahwa pendapat itu dilaksanakan. Dengan demikian, kegiatan pembangunan $\mathrm{HR}$ dengan tujuan untuk meningkatkan partisipasi masyarakat akan tercapai sesuai harapan.

\section{KESIMPULAN}

Berdasarkan hasil analisis yang telah dilakukan dapat disimpulkan bahwa karakteristik masyarakat yang mengelola HR di Desa Bintang Mas, Kecamatan Rasau Jaya didominasi oleh kelompok umur tua, jenis kelamin laki-laki, pendidikan tinggi, penghasilan sedang dengan lama 
tinggal yang sudah lama, sedangkan masyarakat yang mengelola $\mathrm{HR}$ di Desa Kubu Padi Kecamatan Kuala Mandor B didominasi oleh kelompok umur dewasa, jenis kelamin laki-laki, pendidikan tinggi, penghasilan rendah dengan lama tinggal yang sudah lama.

Mayoritas HR yang dikelola masyarakat di Desa Bintang Mas merupakan lahan milik pribadi yang ditanami dengan sistem jalur, monokultur dengan jenis tanaman cepat tumbuh. Pada sisi lain, HR yang dikelola masyarakat di Desa Kubu Padi, Kecamatan Kuala Mandor B adalah lahan milik pribadi, yang ditanami dengan sistem jalur, agroforestry dengan jenis tanaman cepat tumbuh dan MPTS.

Tingkat partisipasi masyarakat dalam pengelolaan $\mathrm{HR}$ di Desa Bintang Mas, Kecamatan Rasau Jaya termasuk dalam kategori rendah; tingkat partisipasi masyarakat Desa Kubu Padi, Kecamatan Kuala Mandor Kabupaten Kubu Raya termasuk dalam kategori sedang. Berdasarakan teori Arnstein, partisipasi masyarakat dalam mengelola HR di Desa Bintang Mas, Kecamatan Rasau Jaya dan Desa Kubu Padi, Kecamatan Kuala Mandor B terdapat pada tangga konsultasi.

Faktor umur, jenis kelamin, pendidikan, pendapatan, dan lama tinggal terhadap tidak berpengaruh nyata terhadap partisipasi masyarakat dalam pengelolaan HR di Desa Bintang Mas, Kecamatan Rasau Jaya, Kabupaten Kubu Raya dan Desa Kubu Padi, Kecamatan Kuala Mandor B. Kegiatan penyuluhan kehutanan serta peluang pasar berpotensi sebagai pendorong partisipasi masyarakat dalam pengelolaan HR di Desa Bintang Mas, Kecamatan Rsau Jaya dan Desa Kubu Padi, Kecamatan Kuala Mandor B Kabupaten Kubu Raya.

27 Jurnal Borneo Akcaya

\section{REKOMENDASI}

Berdasarkan hasil penelitian ini, maka dapat direkomendasikan hal-hal berikut ini :

1. Perlu adanya kebijakan dari pemerintah daerah ataupun pemerintah pusat yang mengatur bahwa masyarakat dalam program HR yang tidak hanya diikutsertakan dalam kegiatan pelaksanaan saja, tetapi juga dilibatkan dari kegiatan perencanaan sampai dengan kegiatan evaluasi. Selain itu, agar masyarakat mempunyai rasa memiliki yang kuat terhadap keberadaan HR, perlu adanya pengadaan bibit tanaman yang berasal dari masyarakat itu sendiri, bukan dari pengadaan pihak ketiga.

2. Perlu kiranya diadakan sosialisasi serta adanya FGD yang terstruktur dan sistematis, sehingga pengetahuan dan wawasan masyarakat pengelola HR dapat meningatkan. Selain itu, peran serta tenaga penyuluh kehutanan serta jaminan pemasaran hasil juga sangat dibutuhkan dalam peningkatan partisipasi masyarakat karena kedua hal ini dapat mempengaruhi tingkat partisipasi masyarakat dalam pembangunan HR.

3. Perlu dilakukan kajian yang mendalam terhadap eksistensi keberadaan kelompok tani serta faktor internal masyarakat yang akan menerima bantuan agar tujuan program dapat dijalankan dan memperoleh capaian yang sesuai dengan harapan.

4. Perlu adanya peraturan daerah yang mengatur tentang keberadaan HR di tingkat kabupaten, sehingga lahan-lahan yang telah menjadi HR tidak bisa dialih fungsikan. 


\section{UCAPAN TERIMA KASIH}

Penulis mengucapkan terima kasih khususnya kepada Dinas Kehutanan Provinsi Kalimantan Barat, Kepala Desa Bintang Mas, Kepala Desa Kubu Padi beserta masyarakatnya yang telah mendukung terlaksananya penelitian, juga kepada Prof. Dr. Ir. H. Abudurrani Muin, M.S yang telah memberikan saran dalam penulisan hasil penelitian ini.

\section{DAFTAR PUSTAKA}

Abdullah, L. (2019). Model Interaksi Pelaku Hutan Rakyat dalam Perdagangan Kayu: Pendekatan Simulasi Model Berbasis Agen (The Interaction Model of Community Forest Behavior in Wood Trade: Agent Based Modelling Approach). Jurnal Penelitian Hutan Tanaman, 16(1), 21-34.

Achmad, B., Diniyati, D., Fauziyah, E., \& Widyaningsih, T. S. (2015). Analisis Faktor-faktor Penentu dalam Peningkatan Kondisi Sosial Ekonomi Petani Hutan Rakyat di Kabupaten Ciamis. Jurnal Penelitian Hutan Tanaman, 12(1), 63-79.

Affandi, M. (2009). Faktor-faktor yang mempengaruhi penduduk lanjut usia memilih untuk bekerja. Journal of Indonesian Applied Economics, 3(2).

Arnstein, S.R. (1969). A Leadder of Citizen Participation. Journal of The American Planning asociation, 35 (4)

Diniyati, D., \& Achmad, B. (2016). Pengaruh Penyuluhan terhadap Pengembangan Kapulaga di Hutan Rakyat: Kasus di Kabupaten Ciamis dan
Tasikmalaya, Jawa Barat. Jurnal Penelitian Sosial dan Ekonomi Kehutanan, 13(1), 25-36.

Eneji, C. V. O., Mubi, M. A., Husain, M. A., \& Ogar, D. A. (2015). Factors Influencing Gender Participation in Forest Resources Management in the Cross River National Park Enclave Communities, Nigeria. Journal of Environment Protection and Sustainable Development, 1(5), 234-244.

Fauziyah, E., Kuswantoro, D. P., \& Sanudin, S. (2016). Prospek Pengembangan Pala (Myristica fragrans Houtt) di Hutan Rakyat. Jurnal IImu Kehutanan, 9(1), 3239.

Hafizianor, H., NP, R. M., \& Zakiah, S. (2016). Analisis Gender Dalam Pengelolaan Agroforestri Dukuh Dan Kontribusinya Terhadap Pendapatan Rumah Tangga Di Desa Kertak Empat Kecamatan Pengaron Kabupaten Banjar Gender Analysis in the Management Agroforestry of Dukuh and Contribution to Houselhold Income of Villages Kertak Empat Districk Pengaron Regency Banjar. Jurnal Hutan Tropis, 3(2).

Hudiyani, I., Purnaningsih, N., Asngari, P. S., \& Hardjanto, H. (2017). Persepsi Petani terhadap Hutan Rakyat Pola Agroforestri di Kabupaten Wonogiri, Provinsi Jawa Tengah. Jurnal Penyuluhan, 13(1), 64-78.

Jallah, Charlene \& Amoakoh, Alex \& , Boateng \& Nortey, Daniel \& Assumadu, Ruth. (2017). Community Participation In Forest Management In The Bleih Community Forest, Nimba County, Liberia. Noth Asian 
Research Journal of Multidisciplinary. 3. 2454-2326.

Kartodihardjo, H., \& Nugroho, B. (2016). Implementation of Hutan Tanaman Rakyat Policy in Muna District Southeast Sulawesi Province Implementasi Kebijakan Hutan Tanaman Rakyat Di Kabupaten Muna Sulawesi Tenggara. Jurnal Silvikultur Tropika, 7(3), 159-164.

Ocloo, J., \& Matthews, R. (2016). From tokenism to empowerment: progressing patient and public involvement in healthcare improvement. BMJ Qual Saf, 25(8), 626-632.

Oktalina, S. N., San Afri Awang, P. S., \& Hartono, S. (2015). Strategi petani hutan rakyat dan kontribusinya terhadap penghidupan di kabupaten Gunungkidul. Jurnal Kawistara, $5(3)$.

Pietersen, S., López-Acosta, J., Gomez-Díaz, J., \& LascurainRangel, M. (2018). Floristic diversity and cultural importance in agroforestry systems on smallscale farmer's livelihoods in Central Veracruz, México. Sustainability, 10(1), 279.

Reski, N. A., Yusran, Y., \& Makkarennu, M. (2017). Rancangan Pemberdayaan Masyarakat pada Pengelolaan Hutan Kemasyarakatan (HKm) Desa Pacekke, Kecamatan Soppeng Riaja, Kabupaten Barru, Sulawesi Selatan. Jurnal Hutan dan Masyarakat, 9(1), 37-43.

Manggala Rimbawati, D. E., Fatchiya, A., \& Sugihen, B. G. (2018). Dinamika Kelompok Tani Hutan Agroforestry di Kabupaten 14(1), 92-103.
Suryatmojo, H. (2018). Bab, I. I. Hutan Rakyat untuk Penataan Lahan dan Pengendalian Daur Air. Hutan Rakyat di Simpang Jalan, 19.

Suryaningsih, W. H. (2012). Persepsi dan Perilaku Masyarakat dalam Upaya Pelestarian Hutan Rakyat di Desa Karangrejo Kecamatan Loano Kabupaten Purworejo (Doctoral dissertation, Program Magister Ilmu Lingkungan Undip).

Susanto, A., \& Sulasno, S. (2017). Analisis Ekonomi Usaha Wanatani Di Kawasan Hutan Rakyat Kecamatan Gemarang Kabupaten Madiun. JURNAL AGRI-TEK, 15(1).

Wahyudi, M. D., \& Christopheros, P. (2018). Kualitas Kayu Sungkai (Peronema canescens) dan Sengon (Paraserianthes falcataria) pada Hutan Rakyat Di Kabupaten Tabalong Kalimantan Selatan. Jurnal Hutan Tropika (ISSN: 1693-7643), 13(1).

Waluyo, E. A., Ulya, N. A., \& Martin, E. (2010). Perencanaan sosial dalam rangka pengembangan hutan rakyat di Sumatera Selatan. Jurnal Penelitian Hutan dan Konservasi Alam, 7(3), 271280.

Wekesa, I.W. (2017). Thesis: Examining The Role of Community Participation in Forest Management and Conservation In Kimothon Forest, Trans Nzoia Country, Kenya. Public Administration, University of Nairobi

Winata, A., \& Yuliana, E. (2012). Tingkat partisipasi petani hutan dalam program pengelolaan hutan bersama masyarakat (PHBM) Perhutani. MIMBAR, Jurnal Sosial dan Pembangunan, 28(1), 65-76 
Younis, A., Younis, I., Elmadina, A. M., Kobbail, A., Yahya, A., Yahya,
A., Yousif,
A. A. (2018).
Oportunities and Constraints to Community Forests for Local Income Generation and Livelihood in Singa Locality , Sennar, 11(3),2-46. 